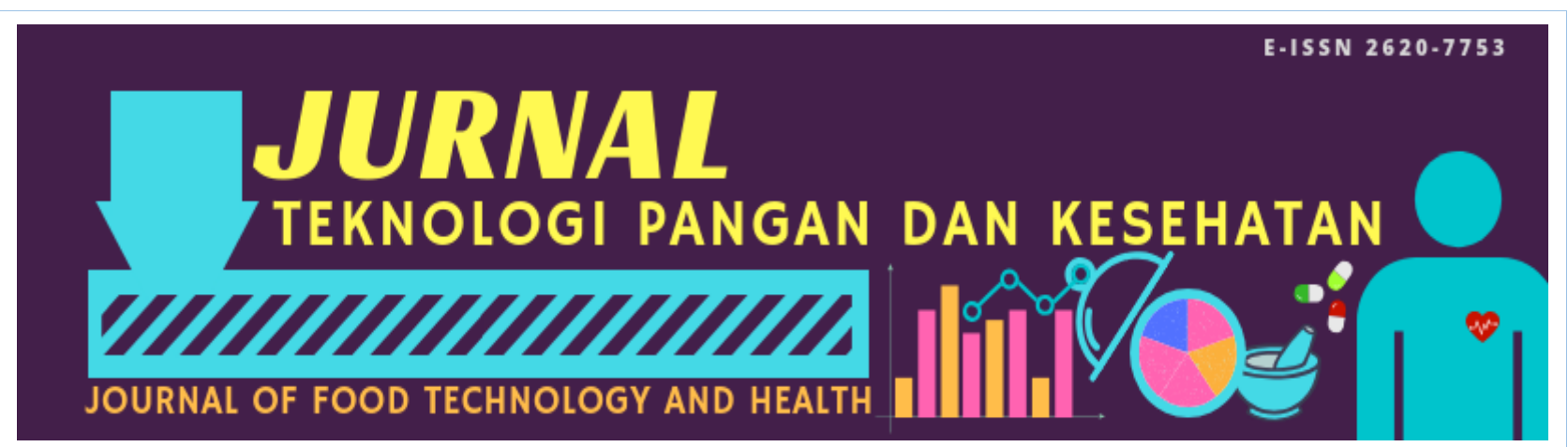

Volume I Nomor I Tahun 2019

Hasil Penelitian

Diterima 11 Jan 2019

Disetujui 29 Mei 2019

\title{
IDENTIFIKASI DAN KARAKTERISASI BAKTERI ASAM LAKTAT PADA ACAR KETIMUN (Cucumis sativus L.) SEBAGAI AGENSI PROBIOTIK
}

\author{
Febry Harissa Surbakti1 ${ }^{*}$, Uswatun Hasanah ${ }^{2}$ \\ ${ }^{1}$ Universitas Sahid, Jakarta; ${ }^{2}$ Universitas Negeri Medan, Medan
}

\begin{abstract}
ABSTRAK: Di Indonesia terkenal dengan berbagai macam makanan tradisional fermentasi. Jenis makanan tradisional yang banyak dijumpai yang diproses dengan menggunakan proses fermentasi adalah tape, asinan, acar dan lainnya yang mengandung banyak bakteri asam laktat (BAL). Bakteri asam laktat ini merupakan kekayaan alam mikroba yang masih harus dieksplorasi dibidang kesehatannya. Penelitian ini bertujuan untuk mengetahui jenis-jenis dan karakteristik bakteri asam laktat yang terdapat pada acar ketimun. Penelitian ini menggunakan metode deskriptif. Teknik pengambilan sampel langsung dilakukan secara aseptis. Bahan yang digunakan adalah bakteri asam laktat yang diambil dari cairan acar ketimun dengan variasi isi ketimun, ketimun nenas, ketimun nenas dan cabai dan ditumbuhkan pada media MRS Broth (de Man Rogosa Sharpe). Berdasarkan hasil penelitian identifikasi dan karakterisasi bakteri asam laktat pada acar ketimun dengan menggunakan uji morfologi, pewarnaan gram dan uji biokimia maka diperoleh 2 jenis bakteri asam laktat pada acar ketimun. Adapun bakteri asam laktat yang ditemukan antara lain adalah Lactobacillus plantarum dan Lactobacillus reuteri. Karakterisitik secara umum adalah basil, gram positif, katalase negatif, tidak motil, suhu optimum $250^{\circ} \mathrm{C}-300^{\circ} \mathrm{C}$ dan memiliki tipe fermentasi heterofermentatif dan homofermentatif.
\end{abstract}

Kata Kunci: Bakteri asam laktat, Probiotik, Acar ketimun

ABSTRACT: In Indonesia it is famous for various kinds of traditional fermented foods. Traditional food types that are often found that are processed using fermentation are tape, pickled, pickled and others that contain a lot of lactic acid bacteria (LAB). This lactic acid bacteria is a natural wealth of microbes that must still be explored in the field of health. This study aims to determine the types and characteristics of lactic acid bacteria found in pickles to Cucumber. This research uses a descriptive method. The direct sampling technique is carried out aseptically. The material used is lactic acid bacteria taken from pickled liquid to Cucumber with various contents to Cucumber, to Pineapple Cucumber, to Cucumber pineapple and chili and grown on MRS Broth media (de Man Rogosa Sharpe). Based on the results of the study of identification and characterization of lactic acid bacteria on pickles to Cucumber using morphological tests, gram staining and biochemical tests, 2 types of lactic acid bacteria were obtained on pickles to Cucumber. The lactic acid bacteria found include Lactobacillus plantarum and Lactobacillus reuteri. General characteristics are basil, gram positive, negative catalase, not motile, optimum temperature 250C300C and have heterofermentative and homofermentative fermentation types.

Keywords: Lactic acid bacteria, Probiotik, Pickled cucumber

\section{PENDAHULUAN}

Bakteri merupakan mikroorganisme yang tersebar luas di alam baik di udara, air, dan di dalam tanah. Bakteri asam laktat (BAL) adalah bakteri yang menguntungkan. Bakteri asam laktat ini merupakan kekayaan alam mikroba yang masih harus dieksplorasi. Secara ekologis kelompok bakteri ini sangat bervariasi dan anggota spesiesnya dapat mendominasi bermacam-macam makanan, minuman dan lain-lain (Yuni, 2013).

Di Indonesia terkenal dengan berbagai macam makanan tradisional fermentasi. Yang tersedia di pasar tradisional maupun pasar moderen. Kebanyakan makanan tradisional fermentasi tersebut diproduksi dalam skala

\footnotetext{
*Email korespondensi: febryharissa@gmail.com
} 
kecil atau skala rumah tangga. Makanan tradisional fermentasi tersebut memegang peranan penting dalam memenuhi kebutuhan makanan sehari-hari masyarakat dan banyak mengandung protein, karbohidrat, dan vitamin (Aryanta dan Tomita, 2000).

Jenis makanan tradisional yang banyak dijumpai yang diproses dengan menggunakan proses fermentasi adalah tape, asinan, acar dan lain sebagainya. Diketahui bahwa proses fermentasi pada makanan bertujuan untuk mengawetkan makanan melalui proses penghambatan bakteri patogen yang dapat membusukkan makanan. Salah satu bakteri yang biasa terdapat dalam proses fermentasi adalah bakteri asam laktat (BAL). Bakteri asam laktat (BAL) adalah kelompok bakteri gram positif, tidak berspora, berbentuk bulat atau batang, memproduksi asam laktat yaitu Lactobacillus sebagai produk akhir selama fermentasi karbohidrat, katalase negatif, mikroaerotoleran dan asidotoleran.

Bakteri asam laktat merupakan bakteri yang diperlukan dalam fermentasi sayuran. Bakteri ini secara alami terdapat pada sayuran itu sendiri. Pemanfaatan bakteri ini yang dikombinasikan dengan pemberian garam dan suhu yang tepat akan menghasilkan produk fermentasi yang bermutu baik (Astuti, 2006).

Acar adalah suatu produk yang mempunyai cita rasa khas yang dihasilkan dari proses fermentasi bakteri asam laktat. Acar digunakan dengan menggunakan proses fermentasi anaerob agar tidak terjadi proses pembusukan (Pusat Penelitian IPB, 2001).

Yuni (2013), menyatakan bahwa bakteri asam laktat (BAL) diketahui mempunyai peranan penting dalam menjaga fisiologis dan kesehatan manusia yaitu berfungsi menjaga sistem kekebalan tubuh. Sepanjang hari bakteri ini akan mengenali mikroorganisme patogen yang berbahaya dan bahan-bahan asing lainnya yang ada dalam tubuh kita. Salah satu upaya untuk meningkatkan sistem kekebalan tubuh adalah dengan mengkonsumsi probiotik guna menunjang metabolisme tubuh.
Di antara galur-galur bakteri asam laktat, terdapat perbedaan kemampuan dalam menghambat pertumbuhan bakteri perusak dan patogen. Oleh sebab itu dalam penelitian ini akan diisolasi bakteri asam laktat dari pikel ketimun yang merupakan produk fermentasi spontan (fermentasi tanpa stater) oleh bakteri asam laktat (Pusat Penelitian IPB, 2001).

Berdasarkan latar belakang di atas maka perlu dilakukan suatu identifikasi BAL yang tumbuh dalam biakan atau medium buatan untuk melihat jenis bakteri asam laktat yang tumbuh akibat proses fermentasi pada acar. Selain itu akan dilihat karakteristik bakteri asam laktat melalui suatu cara yang digunakan untuk menentukan jenis spesies yang sudah diidentifikasi dengan uji morfologi, uji biokimia yang meliputi uji katalase dan uji tipe fermentasi.

\section{METODE PENELITIAN Sampel dan Media}

Sampel dalam penelitian ini adalah bakteri asam laktat (BAL) yang dibuat sendiri dan berasal dari acar ketimun yang berbagai macam isi yaitu berisi ketimun, nenas, dan cabai rawit dengan menambahkan larutan garam dengan konsentrasi $5 \% \mathrm{NaCl}$. Sebanyak 1\% glukosa ditambahkan untuk membantu fermentasi. Pengambilan dilakukan dengan cara aseptik dengan menggunakan wadah, kantong plastik steril dan aluminium foil, selanjutnya sampel dibawa ke Laboratorium Mikrobiologi Balai Laboratorium Kesehatan Medan untuk dianalisis. BAL ditumbuhkan pada media MRS (de Man Rogosa Sharpe) broth dan MRS agar.

Metode pembuatan media MRS broth dan MRS agar dengan menimbang media MRS broth sebanyak 52,5 gram, lalu menambahkan ke dalam $1000 \mathrm{ml}$ akuades dalam erlenmeyer. Untuk MRS agar ditambah Agar powder 1 bungkus, kemudian dipanaskan di atas hot plate hingga mendidih dan disterilkan dengan autoklaf suhu $121^{\circ} \mathrm{C}$ selama 15 menit, kemudian membagi ke dalam cawan petri (MRS Agar) dan tabung reaksi (MRS Broth) yang sudah steril dan menyimpan ke dalam lemari dengan suhu 
ruang $\left(27^{\circ} \mathrm{C}\right)$ selama 24 jam lalu dimasukkan ke dalam refrigenerator.

\section{Isolasi Bakteri Asam Laktat (Pusat Penelitian IPB, 2001)}

Isolasi bakteri asam laktat dari acar ketimun dipelihara di media MRS Agar, sedangkan MRS Broth untuk menumbuhkan kultur kerja bakteri asam laktat. Cairan dari acar ketimun dan acar diencerkan dengan larutan NaCL 0,9\% sampai pengenceran $10^{-5}$. Sebanyak $1 \mathrm{ml}$ contoh dari pengenceran $10^{-4}$ - 10-5 diambil dan dipindahkan ke dalam cawan petri steril (dilakukan duplo untuk setiap pengenceran). Agar MRS dituangkan ke dalam cawan petri dan di goyang secara mendatar. Setelah agar beku, cawan diinkubasi dalam posisi terbalik pada suhu $27^{\circ} \mathrm{C}$ selama dua hari. Cawan dengan kolonikoloni yang terpisah dipilih, koloni-koloni yang mempunyai warna dan ukuran yang berbeda dipindahkan ke dalam cawan petri yang berisi agar MRS dan membuat goresan kuadran. Inkubasi dilakukan pada suhu $27^{\circ} \mathrm{C}$ selama dua hari (Pusat Penelitian IPB, 2001). Jika koloni dalam cawan petri belum murni (misalnya koloni tidak seragam ) maka diambil satu koloni dan dibuat goresan kuadran lagi pada agar MRS sampai diperoleh koloni-koloni dengan ukuran yang seragam seperti perkembangan bentuk sel, tipe pergandengan sel, warna koloni, bentuk koloni dan tipe koloni yang telah murni. Isolasi bakteri asam laktat yang telah murni ditumbuhkan dalam MRS broth selama 2 hari. Kultur ini akan digunakan sebagai inokulum untuk identifikasi awal.

\section{Identifikasi Bakteri Asam Laktat (Pusat Penelitian IPB, 2001) Identifikasi awal}

Identifikasi awal meliputi uji katalase dan pewarnaan gram. Untuk uji katalase, satu loop kultur cair disebarkan pada gelas objek. Larutan $\mathrm{H}_{2} \mathrm{O}_{2}$ 3\% diteteskan di atas kultur tersebut. Timbulnya gelembung-gelembung oksigen pada kultur menunjukkan uji positif. Bakteri asam laktat akan menunjukkan uji katalase negatif. Untuk pewarnaan gram, satu loop kultur cair disebarkan pada gelas obyek. Kultur cair dikeringkan di udara dan difiksasi dengan nyala api kecil. Pewarna kristal violet diteteskan di atas film pada gelas objek selama 1 menit, kemudian dibilas dengan air kran. sisa air yang tertinggal dibuang, dan lapisan film kultur ditetesi dengan larutan Lugol (yodium Gram) selama 1 menit. Setelah dicuci kembali dengan air, kemudian dihilangkan warnanya dengan menggunakan alkohol 95\% selama 10-20 detik atau sampai warna biru tidak luntur lagi. Setelah dicuci sebentar, kemudian lapisan film kultur diwarnai dengan larutan safran in selama 10-20 detik. Setelah dibilas dengan air dan dikeringkan dengan kertas serap, lapisan film bakteri diperiksa di bawah mikroskop dengan pembesaran 1000 kali. Bakteri asam laktat merupakan bakteri gram positif ditandai dengan kultur yang berwarna biru-ungu.

\section{Uji Biokimia Bakteri Asama Laktat}

Pengamatan dilakukan dengan menumbuhkan kultur isolat dalam media MRS cair dalam tabung reaksi yang diberi tabung durham dalam keadaan terbalik untuk menangkap gas yang dihasilkan oleh bakteri asam laktat selama dalam pertumbuhannya. Selanjutnya dilakukan inkubasi selama 2-3 hari pada suhu $270^{\circ} \mathrm{C}$.

Bakteri asam laktat heterofermentasi yang diuji menghasilkan gas di dalam tabung durham, sedang bakteri asam laktat homofermentasi yang diuji tidak akan menghasilkan gas di dalam tabung durham. Berikut skema prosedur kerja bakteri asam laktat (BAL).

\section{Pengamatan Morfologi Bakteri (Ibrahim et al., 2015).}

Pengamatan pertumbuhan koloni bakteri pada medium agar lempeng yaitu bentuk, tepian elevasi, permukaan warna.

\section{Pengamatan Morfologi Sel}

Untuk pewarnaan Gram, gelas objek dibersihkan dengan alkohol 70\% dan diberi akuades, kemudian dipanaskan di atas nyala api kemudian diambil secara aseptik 1 ose biakan bakteri, diratakan pada kaca objek dan difiksasi di atas nyala api. Kemudian ditetesi dengan larutan kristal violet, dan didiamkan selama 1 menit, lalu dicuci dengan 
air mengalir dan dikeringkan. Selanjutnya ditetesi dengan larutan yodium dan dibiarkan selama 1 menit, lalu dicuci dengan air mengalir dan keringkan lalu dicuci dengan larutan pemucat selama 30 detik, dicuci dengan air mengalir dan dikeringkan. Setelah itu ditetesi dengan larutan safranin atau zat penutup dan didiamkan selama 2 menit, kemudian dicuci dengan air mengalir dikeringkan dan diamati dengan menggunakan mikroskop pada perbesaran kuat (1.000x). Indikasi pewarnaannya yaitu bakteri gram positif akan berwarna violet dan bakteri gram negatif akan berwarna merah. Diamati pula bentuk dari sel bakteri tersebut apakah cocus, basil maupun spiral.

\section{HASIL DAN PEMBAHASAN Hasil Pengamatan Morfologi}

Hasil pengamatan morfologi BAL pada acar terdiri dari warna, tepi dan bentuk serta ditambahkan dengan pewarnaan gram untuk memastikan apakah benar bakteri tersebut adalah BAL.

Tabel 1. Data Hasil Pengamatan Morfologi koloni Bakteri Asam Laktat

\begin{tabular}{|c|c|c|c|c|c|}
\hline \multicolumn{2}{|c|}{ Acar Ketimun } & \multicolumn{3}{|c|}{ Uji Morfologi (Koloni) } & \multirow{2}{*}{$\begin{array}{c}\text { Pewarnaan } \\
\text { Gram } \\
+\end{array}$} \\
\hline Sampel & Pengenceran & Warna & Tepi & Bentuk & \\
\hline \multirow{2}{*}{$\begin{array}{l}\text { Ketimun } \\
\text { (T) }\end{array}$} & $10^{-4}$ & Putih Susu & Cembung & $\begin{array}{l}\text { Bulat } \\
\text { Keruh }\end{array}$ & + \\
\hline & $10^{-5}$ & Putih Susu & Cembung & $\begin{array}{l}\text { Bulat } \\
\text { Keruh }\end{array}$ & + \\
\hline \multirow{2}{*}{$\begin{array}{l}\text { Ketimun } \\
\text { Nenas } \\
\text { (TN) }\end{array}$} & $10^{-4}$ & Putih Susu & Cembung & $\begin{array}{l}\text { Bulat } \\
\text { Keruh }\end{array}$ & + \\
\hline & $10^{-5}$ & Putih Susu & Cembung & $\begin{array}{l}\text { Bulat } \\
\text { Keruh }\end{array}$ & + \\
\hline \multirow{2}{*}{$\begin{array}{c}\text { Ketimun } \\
\text { Nenas } \\
\text { Cabai } \\
\text { (TNC) }\end{array}$} & $10^{-4}$ & Putih Susu & Cembung & $\begin{array}{l}\text { Bulat } \\
\text { Keruh }\end{array}$ & + \\
\hline & $10^{-5}$ & Putih Susu & Cembung & $\begin{array}{l}\text { Bulat } \\
\text { Keruh }\end{array}$ & + \\
\hline
\end{tabular}

Dari Tabel 1 pengamatan morfologi koloni bakteri asam laktat di atas dapat diketahui bahwa, setiap pengenceran $10^{-4}$ dan $10^{-5}$ pada sampel ketimun, ketimun nenas, dan ketimun nenas cabai memiliki morfologi yang sama, yaitu memiliki warna putih susu, tepi cembung dan struktur bulat keruh. Adapun hasil uji pewarnaan atau pengecatan gram bakteri asam laktat dari acar ketimun, ketimun nenas, dan ketimun nenas cabai mengasilkan pewarnaan atau pengecatan gram positif $(+)$, dengan ditandai morfologi bakteri berwarna ungu saat diamati dibawah mikroskop dengan perbesaran 1000x.

\section{Hasil Pengamatan Pewarnaan Gram dan Uji Biokimia}

Dari Tabel 2 pengamatan pewarnaan gram dan uji biokimia koloni bakteri asam laktat di atas dapat diketahui bahwa, katalase negatif $(-)$, pengenceran $10^{-4}$ dan $10^{-5}$ pada sampel acar ketimun memiliki bentuk sel basil (batang), produksi gas positif $(+)$, tipe fermentasinya heterofermentatif dan hasil pewarnaan gram positif $(+)$ serta uji biokimia dari acar ketimun tersebut ditemukan bakteri asam laktat dengan spesies Bacillus plantarum. Sedangkan pengenceran $10^{-4}$ dan $10^{-5}$ pada sampel acar ketimun nenas dan ketimun nenas cabai memiliki bentuk sel basil (batang), produksi gas negatif (-), tipe fermentasinya homofermentatif dan hasil pewarnaan gram positif $(+)$ serta uji biokimia dari acar ketimun tersebut menghasilkan bakteri asam laktat dengan spesies Bacillus reuteri.

Berdasarkan penelitian yang dilakukan diketahui bahwa pertumbuhan bakteri pada acar ketimun yang ditumbuhkan pada media MRS agar mengalami pertumbuhan yang berbeda, berdasarkan variasi isi pada acar. Pada acar ketimun dan acar ketimun nenas pertumbuhan bakteri terjadi pada hari ke 2, sedangkan pada acar ketimun nenas cabai 
pertumbuhan bakteri terjadi pada hari ke 6 . Dengan demikian dapat dikatakan bahwa pertumbuhan pada acar ketimun nenas cabai mengalami pertumbuhan bakteri yang sangat lambat.

Adapun penyebab lama pertumbuhan bakteri asam laktat pada acar ketimun nenas cabai disebabkan oleh senyawa bioaktif yang terdapat pada cabai. Menurut Astuti (2006), cabai mengandung zat capsaicin (minyak atsiri). Pada umumnya, minyak atsiri berperan sebagai pengahambat bakterisida dan fungisida yang bersifat penghambat spesifik.

Tabel 2. Data Hasil Pengamatan Pewarnaan Gram \& Uji Biokimia Koloni BAL

\begin{tabular}{ccccccc}
\hline & \multicolumn{2}{c}{ Acar Ketimun } & & \multicolumn{2}{c}{ Uji Biokimia } \\
\hline Sample & Pengenceran & $\begin{array}{c}\text { Bentuk } \\
\text { Sel }\end{array}$ & Katalase & $\begin{array}{c}\text { Produksi } \\
\text { Gas }\end{array}$ & Tipe Fermentasi & Jenis \\
\hline $\begin{array}{c}\text { Ketimun } \\
(\mathrm{T})\end{array}$ & $10^{-4}$ & Basil & - & + & Heterofermentatif & $\begin{array}{c}\text { Bacillus } \\
\text { plantarum }\end{array}$ \\
\cline { 2 - 7 } & $10^{-5}$ & Basil & - & + & Heterofermentatif & $\begin{array}{c}\text { Bacillus } \\
\text { plantarum }\end{array}$ \\
\hline $\begin{array}{c}\text { Ketimun } \\
\text { Nenas } \\
(\mathrm{TN})\end{array}$ & $10^{-4}$ & Basil & - & - & Homofermentatif & Bacillus reuteri \\
\hline $\begin{array}{c}\text { Ketimun } \\
\text { Nenas } \\
\text { Cabai } \\
(\mathrm{TNC})\end{array}$ & $10^{-5}$ & Basil & - & - & Homofermentatif & Bacillus reuteri \\
\hline
\end{tabular}

\section{Uji Morfologi}

Isolasi bakteri yang diperoleh dari cairan acar ketimun ditumbuhkan pada media MRS Broth dengan metode pour plate dan spread plate dan dilakukan pemurnian dengan metode goresan (streak plate) pada media MRS Agar hingga diperoleh isolat murni, kemudian diinkubasi selama 48 jam pada suhu $270^{\circ} \mathrm{C}$. Ditemukan adanya dua koloni bakteri yakni putih susu dan putih keruh, tetapi bentuk dan tipe serta warna koloni bakteri yang mencirikan bakteri asam laktat adalah koloni yang berwarna putih susu dengan bentuk bulat buram dengan tepi yang cembung.

\section{Pewarnaan Gram dan Uji Biokimia}

Pengamatan dilanjutkan dengan pewarnaan gram untuk mengetahui karakteristik sel dari setiap isolat bakteri melalui preparat yang terlebih dahulu diwarnai dengan prosedur pewarnaan gram. Pengamatan pada semua preparat menggunakan mikroskop perbesaran $100 \mathrm{x}$ dan 1000x, hasilnya menunjukan isolat berbentuk batang (basil) dan ditandai dengan warna sel ungu. Dapat disimpulkan bahwa semua isolat bakteri tersebut merupakan bakteri Gram positif.

Selanjutnya dilakukan dengan pengujian biokimia untuk mengetahui karakteristik khusus dari setiap jenis isolat bakteri asam laktat yang ada, hingga diketahui spesies bakteri asam laktat yang terdapat pada cairan acar ketimun. Berdasarkan uji biokimia yang diperlihat pada Tabel 2 memperkuat dengan bahwa isolat bakteri asam laktat yang diperoleh berjumlah 2 spesies dari 1 genus yang sama. Hal tersebut disebabkan karena pada setiap bakteri memiliki karakteristik biokimia tersendiri yang disebut biochemical fingerprints. Dengan demikian diperoleh 2 spesies dari 1 genus bakteri asam laktat yaitu; Genus Lactobacillus memiliki 2 spesies Lactobacillus plantarum dan Lactobacillus reuteri.

Menurut Yuni (2013), bakteri Lactobacillus ini termasuk gram positif (+), katalase negatif $(-)$, tidak berspora, tidak motil, fakultatif anaerob, kadang-kadang mikroaerofilik, sedikit tumbuh di udara tapi bagus pada keadaan di bawah tekanan oksigen rendah, dan beberapa anaerob pada isolasi. Lactobacillus ada yang heterofermentatif dan homofermentatif. 
Pada bakteri asam laktat, Lactobacillus yang heterofermentatif ditandai dengan ada gelembung gas pada tabung durham saat melakukan uji fermentasi dan disebut fermentasi positif (+). Sedangkan Lactobacillus yang homofermentatif ditandai dengan tidak adanya gelembung gas pada tabung durham saat melakukan uji fermentasi dan disebut fermentasi negatif (-). Pada pengamatan, spesies Lactobacillus yang heterofermentatif yaitu Lactobacillus plantarum. Sedangkan spesies Lactobacillus yang homofermentatif yaitu Lactobacillus reuteri.

Koloni pada media MRS agar biasanya 2-5 $\mathrm{mm}$, cembung, bulat buram dan tanpa pigmen, kemoorganotrof, metabolismenya adalah fermentatif dan sacharoclastic. Tumbuh optimum pada suhu $25-30^{\circ} \mathrm{C}$. Lactobacillus tersebar luas di lingkungan, terutama pada hewan dan produk makanan sayur-sayuran.

Berdasarkan Bergey's Manual of Determinative Bacteorology (1974), dari dua spesies bakteri asam laktat yang diperoleh dapat diketahui karakterisasi yang dimiliki oleh masing-masing bakteri asam laktat.

Lactobacillus plantarum memiliki klasifikasi ilmiah

$\begin{array}{ll}\text { Kerajaan } & : \text { Bakteri } \\ \text { Devisi } & : \text { Firmicutes } \\ \text { Kelas } & : \text { Bacilli } \\ \text { Ordo } & : \text { Lactobacillales } \\ \text { Famili } & : \text { Lactobacillaceae } \\ \text { Genus } & : \text { Lactobacillus } \\ \text { Spesies } & : \text { Lactobacillus plantarum }\end{array}$

Karakteristik bakteri Lactobacillus plantarum saat diamati dibawah mikroskop dengan perbesaran 1000x, berbentuk batang (basil), berwarna violet dan terletak sangat rapat pada bakteri Lactobacillus plantarum lainnya (Buchanan \& Gibbon, 1974).

Menurut Hidayat (2006), Lactobacillus plantarum mampu menghambat bakteri bakteri patogen seperti E. coli, B. subtilis, $S$. aureus, bakteri-bakteri Gram negatif dan beberapa bakteri lain sehubungan dengan kemampuannya memproduksi asam laktat, $\mathrm{H}_{2} \mathrm{O}_{2}$ dan bakteriosin seperti plantaricin.

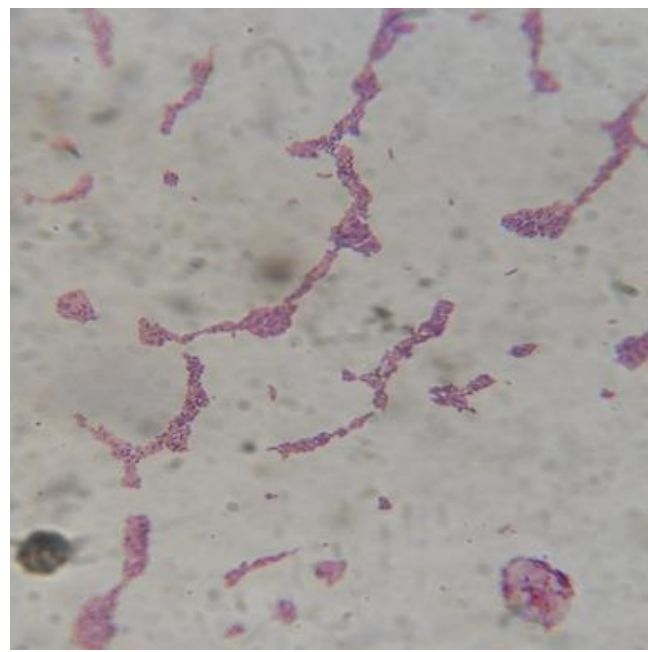

Gambar 1. Lactobacillus plantarum dibawah mikroskop, perbesaran 1000x

Lactobacillus reuteri memiliki klasifikasi ilmiah

Kerajaan : Bakteri

Devisi : Firmicutes

Kelas : Bacilli

Ordo : Lactobacillales

Famili : Lactobacillaceae

Genus : Lactobacillus

Species : Lactobacillus reuteri

Pada spesies bakteri asam laktat diatas tipe fermentasinya homofermentatif, karena pada saat uji katalase Lactobacillus reuteri tidak mengeluarkan atau mengasilkan gas pada tabung durham (Yuni, 2013).

Karakteristik bakteri Lactobacillus reuteri saat diamati dibawah mikroskop dengan perbesaran 1000x, berbentuk batang (basil), berwarna violet dan terletak menyebar.

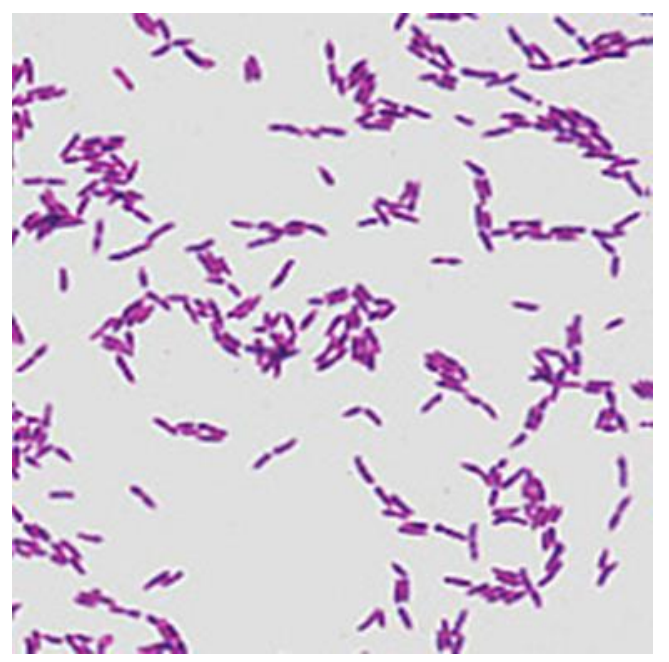

Gambar 2. Lactobacillus reuteri dibawah mikroskop, perbesaran $1000 x$ 


\section{KESIMPULAN}

Berdasarkan penelitian yang dilakukan pada acar ketimun yang berasal dari cairan acar ketimun dengan variasi isi ketimun, ketimun dan nenas, ketimun nenas dan cabai dapat disimpulkan bahwa jenis bakteri asam laktat yang terdapat pada acar ketimun dapat berperan sebagai agensi probiotik adalah Lactobacillus plantarum dan Lactobacillus reuteri. Karakteristik pada tiap-tiap jenis bakteri asam laktat tersebut secara umum memiliki ciri dan sifat gram positif, katalase negatif, tidak berbentuk spora, secara umum tidak motil tetapi ada beberapa yang motil. Karakteristik khusus yang dimiliki Lactobacillus plantarum dan Lactobacillus reuteri berbentuk batang (basil). Selain itu berdasarkan tipe fermentasinya Lactobacillus plantarum merupakan heterofermentatif dan Lactobacillus reuteri merupakan homofermentatif.

\section{DAFTAR PUSTAKA}

Astuti, S.M., 2006. Teknik pelaksanaan percobaan pengaruh konsentrasi garam dan blaching terhadap mutu acar buncis, Jakarta: Buletin Teknik Pertanian.

Aryanta, \& Tomita, F., 2000, Identification and succession of lactic acid bacteria during fermentation of "urutan", a Balinese indigenous fermented sausage. W. J. Microbiol. Biotechnol., 18, pp. 255262.

Buchanan, R.E., \& Gibbon, N.E., 1974. Bergey's manual of determinative Bacteriology. 8th Ed., The Williams and Wilkins, Baltimore.

Ibrahim, A., Fridayanti, A., \& Delvia, F., 2015. Isolasi dan identifikasi bakteri asam laktat (BAL) dari buah mangga (Mangifera indica L.). Jurnal Ilmiah Manuntung, 2(1), hal. 159-163.

Pusat Penelitian IPB, 2001. Isolasi dan identifikasi bakteri asam laktat dari acar, Penelitian, Institut Pertanian Bogor.

Yuni, N.S.M., 2013. Isolasi, karakterisasi, dan identifikasi DNA bakteri asam laktat (BAL) yang berpotensi sebagai antimikroba dari fermentasi markisa kuning (Passiflora edulis var. flavicarpa). J. Kimia Unand, 2(2), hal. 81-91.

\section{BIODATA}

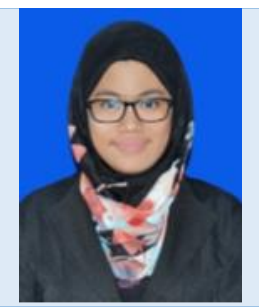

Febry Harissa, S.Si., MSi, Lahir di Tebing Tinggi, , 27 Februari 1990. Meraih gelar S.Si tahun 2012 dari Program Studi Biologi, FMIPA, Universitas Negeri Medan. Melanjutkan program magister pada tahun 2015 pada Program Studi Gizi Masyarakat, Institut Pertanian Bogor. Kini aktif sebagai dosen di Program Studi Gizi, Fakultas Teknologi Pangan dan Kesehatan, Universitas Sahid Jakarta. Email: febry_harissa@yahoo.com, Instagram: @febryharissa 